\title{
Study of the effect of baffles on longitudinal stability of partly filled fuel tanker semi-trailer using CFD
}

\author{
Hong Duc Thong ${ }^{1,2}$, Tran Minh Tai ${ }^{1,3}$, Huynh Phuoc Thien ${ }^{3, *}$
}

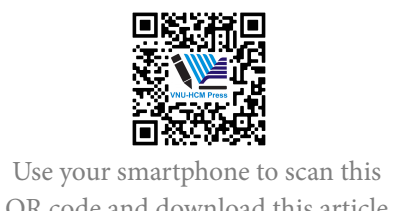

QR code and download this article

${ }^{1}$ Department of Automotive Engineering, Faculty of Transportation Engineering, Ho Chi Minh City University of Technology (HCMUT)

${ }^{2}$ Vietnam National University Ho Chi Minh City (VNU - HCM)

${ }^{3}$ Department of Automotive Engineering, Faculty of Automotive Engineering, Cao Thang Technical College (CTCT)

\section{Correspondence}

Huynh Phuoc Thien, Department of Automotive Engineering, Faculty of Automotive Engineering, Cao Thang Technical College (CTCT)

Email:

huynhphuocthien@caothang.edu.vn

History

- Received: 09-8-2019

- Accepted: 27-12-2020

- Published: 22-01-2021

DOI : 10.32508/stdjet.v3iSI2.538

\section{Check for updates}

\section{Copyright}

( ) VNU-HCM Press. This is an openaccess article distributed under the terms of the Creative Commons Attribution 4.0 International license.

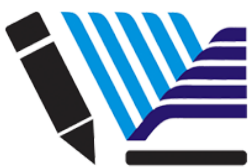

VNU-HCM Press

\begin{abstract}
Sloshing of liquid in partially filled fuel tanker vehicles has a strong effect on the directional stability and safety performance. Under the maneuver of the vehicle, such as steering, braking, or accelerating, the liquid fuel in the tanker tends to oscillate. As a result, hydrodynamic forces and moments raise. It leads to reduce the stability limit and the controllability of the vehicle. To minimize the effect of sloshing, the baffles are usually added to the tanker. This paper presents the study of the effect of baffles on the longitudinal stability of the fuel tanker semi-trailer using the computational fluid dynamics (CFD) approach. A three-dimensional fluid dynamic model of a typical tanker with different baffle configurations is developed. The User Defined Function (UDF) is used to control the acceleration of the tanker according to the simulation scheme. Transient simulations are performed for the cases of constant acceleration longitudinal maneuvers with different levels of fuel in the tanker. The volume of fluid (VOF) and air obtained from the simulation is used to indirectly calculate the center of gravity of the tanker. The post-processing results show that the baffles could provide resistance to the fluid sloshing, resulting in an improvement of the longitudinal stability of the tanker semi-trailer. The results also prove that the benefit of the baffle to the fuel tanker vehicle's stability depends on the size of the baffle, as well as the number of baffles. The $40 \%$ height three baffles model is the proper baffle model to resist the longitudinal sloshing in the partially filled tanker of the studied trailer. By adding baffles, shifting of load on the kingpin and the rear axis are less than $5 \%$ and $2 \%$ as the tanker is filled with $50 \%$ and $70 \%$ fluid level respectively.
\end{abstract}

Key words: Baffle, longitudinal dynamic fluid slosh, sloshing simulation, tanker semi-trailer

\section{INTRODUCTION}

As a tanker semi-trailer with a partially filled liquid tanker is in acceleration or deceleration, the carrying fluid tends to oscillate. This phenomenon is preferred as sloshing, a form of fluid-structure interaction. One of the major effects of sloshing is to cause the change of the center of gravity of the fluid when the tanker semi-trailer doing the braking or turning maneuver. As a result, the dynamic load shift in the roll and pitch planes could affect the roll and pitch moments, and the mass moments of inertia of the fluid cargo and may lead to a reduction in the directional stability limits and the controllability of the vehicle.

To prevent large scale sloshing, baffles are usually added to the tanker structure. Studies on the effect of baffle configuration on sloshing phenomenon using both theoretical and experimental approach have been carried out for the past several decades. However, only a few theoretical studies deal with the complicated case of sloshing such as tanker semi-trailer in braking or turning maneuver. The experimental approach could give a visual view of sloshing. But, it requires well preparation of equipment such as excitation system, acceleration acquisition system and wave-height measurement system ${ }^{1}$. In addition, it is difficult to carry out the experiment on large testing objects $^{2}$.

In recent years, the numerical approach using Computational Fluid Dynamics (CFD) analysis plays an important role in predicting the behavior of fluidstructure interaction in the sloshing. Time and costsaving can be achieved by using the CFD as a tool to find out the proper model in a group of potential models. Besides that, CFD can deal with the flow limitation and the complicated boundary condition. Several techniques have been used to numerical simulate of liquid sloshing, consisting of boundary element integral methods, finite element methods for potential flow, finite difference/volume methods solving the Navier-Stokes equations, and the smoothed particle hydrodynamics method ${ }^{2}$. Among these numerical approaches, the method based on Navier - Stokes solver coupled with the Volume-of-Fluid (VOF) technique is proper to simulate large-amplitude fluid slosh under time-varying excitation acceleration, as well as to track the liquid free surface ${ }^{3}$.

In this paper, the study of the effect of baffles configuration on the longitudinal stability of an ellipse cross- 
section tanker semi-trailer is discussed. The Ansys Fluent software is used to solve the Navier - Stoke equation. The Volume of Fluid model is chosen to formulate the interaction of multiphase of fluid in the tanker ${ }^{4}$. The User-Defined-Function (UDF) is used to vary the acceleration of the tanker according to the simulation scheme.

\section{METHODOLOGY}

\section{Physical Model and Static Stability Analysis}

The study is carried out on the tanker semi trailer's model of KCT G43-BX40-02 made by Tan Thanh Trading Mechanic Corp, Viet Nam ${ }^{5}$. The main components of the trailer are shown in Figure 1. Detail of load distribution on the kingpin and the rear axles is illustrated in Table 1.

\section{Simulation Modelling}

\section{Numerical Model}

The numerical simulation is done on the fuel tanker semi-trailer G43-BX40-02. To simplify, the tanker is considered to have ellipse cross-section with the dimension of $2.5 \mathrm{~m}$ in height $1.96 \mathrm{~m}$ in wide. The total length of the tanker is $10.5 \mathrm{~m}$. The fore and aft bulkheads of the tanker are assumed to be flat, and the baffles are also flat. The origin of the coordinate system used is located at the geometric center of the tanker, the $\mathrm{x}$-axis is along the longitudinal axis of the tanker, the $\mathrm{z}$-axis is in the vertical direction. The baffles are installed in the lateral plane with equal distance along the $\mathrm{X}$-axis, and symmetry about the OXY plane axis is in the vertical direction. Figure 2 depicts the overall dimension of the tanker.

There baffle configurations that have quantity of baffle of 3,4 , and 5 are considered. On each configuration, the baffles' height is set to $30 \%, 40 \%$, and $50 \%$ of the tanker's height. In general, baffles are flat, the overall shape of baffle is similar to the tanker cross-section. The baffle is symmetric about the longitudinal and lateral axles. The baffles that have a height of $40 \%$ and $50 \%$ of the tanker's height are shown in Figure 3.

The simulations were performed under time-varying acceleration along the longitudinal axis as showed in Figure 4 . In the first 0.1 seconds of the simulation, the acceleration is set to zero. The fuel tanker vehicle is then accelerated at a constant acceleration of $0.7 \mathrm{~m} / \mathrm{s}^{2}$ in 7.9 seconds. As the vehicle reaches the velocity of $20 \mathrm{~km} / \mathrm{h}$, its acceleration is then set to 0 and remain at that value for the rest of simulation. For all of the simulation, the translation acceleration is set to 9.81 $\mathrm{m} / \mathrm{s}^{2}$ in the direction of $-\mathrm{Z}$-axis ${ }^{6}$.

\section{Simulation method}

The simulation of sloshing of fluid in the fuel tanker under the time-varying acceleration excitation is done using the commercial Computation Fluid Dynamics software, namely Ansys Fluent version 18.2. The process of simulation and post- processing of the results is illustrated in the flowchart in Figure 5.

The Fluid Flow (Fluent) module of Ansys Workbench is used to create the geometry of the tanker and baffles. The unstructured mesh is used to smooth the transition at the tanker wall and the baffles. The mesh quality is controlled to be fined during the automatic mesh generation. The wireframe view of the mesh is shown in Figure 6, while the detail of the mesh is listed in Table 2.

In order to track the center of gravity of the fluid sloshing, the Volume of Fluid (VOF) multiphase model is activated in the solving model of Ansys Fluent. Two phases of air and gasoline are used to represent the gasoline and air in the partially filled tanker. The VOF model was designed to capture the position of the interface between two immiscible fluids.

The volume fraction of each phase in every cell is tracked throughout the domain by a set of momentum equation between phases. The VOF model relies on the hypothesis that the fluids are not interpenetrating. In each computational cell, the total volume fraction of all phases equal to $1^{4}$. The detail of the solver and the fluid properties are illustrated in Table 3.

In order to model the time-varying acceleration motion of the tanker, the User-Defined-Function (UDF file) is used. This file describes the motion of the tankers' geometry according to the model of the tanker's acceleration. By running the Ansys Fluent on the Visual Studio Developer Command Prompt, the UDF file can be built, loaded into a library in Fluent. The functions defined by the UDF file will control the motion of the mesh via the setting in the dynamic mesh task page of Fluent ${ }^{7}$.

\section{Post processing of simulation results}

The exported data is set to contain the information of the volume of each computational cell of the mesh $V_{c}$, and the volume fraction of liquid in each cell, $\operatorname{vof}(c)_{\text {gas }}$. As a result, the mass of liquid in each cell can be calculated by the formula:

$$
M_{c}=\rho_{g a s} . V_{c} \cdot \operatorname{vof}(c)_{g a s}
$$

Three cases are existing for the value of $v o f(c)_{\text {gas }}$ :

- $\operatorname{vof}(c)_{\text {gas }}=1:$ the cell full of gasoline

- $v o f(c)_{\text {gas }}=0$ : the cell full of air (empty of gasoline) 


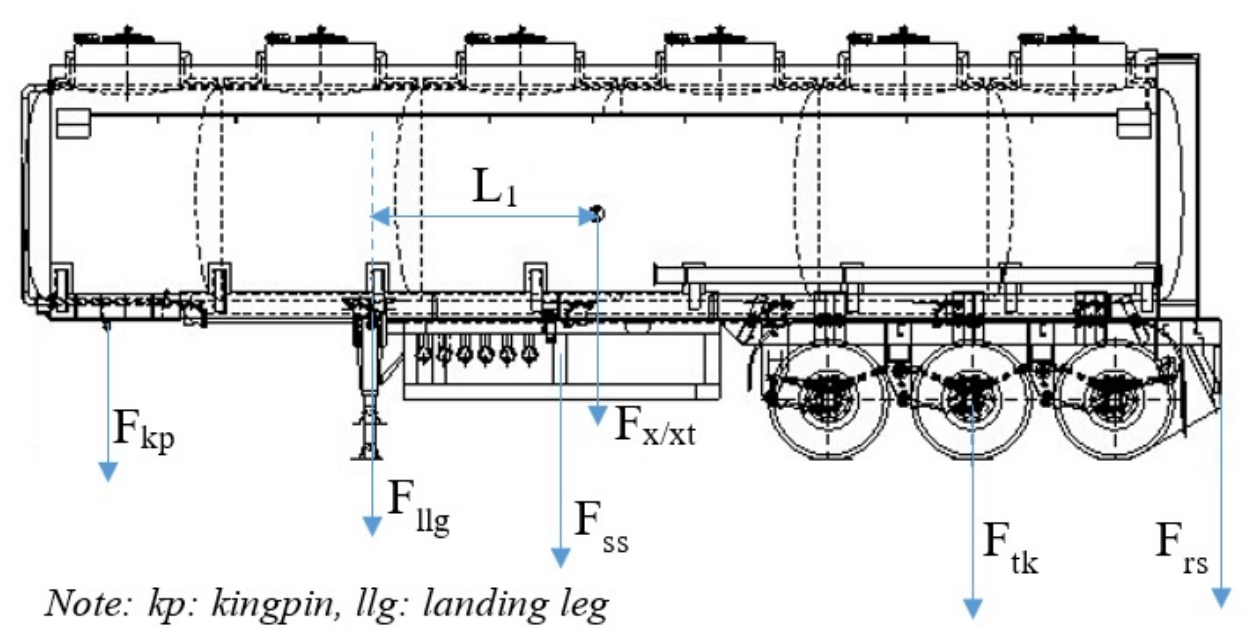

ss: side shield, tk: tanker, rs: rear shield

Figure 1: Forces acting on the trailer

Table 1: Load distribution on the kingpin and rear axles

\begin{tabular}{lllll}
\hline No. & Quantity & Value $(\mathrm{kg})$ & Load on kingpin $(\mathrm{kg})$ & $\begin{array}{l}\text { Load on rear } \\
\text { axles }(\mathrm{kg})\end{array}$ \\
1 & Plate to install kingpin & 115 & 115 & 0 \\
2 & Landing leg & 150 & 105 & 45 \\
3 & Side shield & 80 & 40 & 40 \\
4 & Main beam \& accessory & 3870 & 0 & 3870 \\
5 & Rear shield \& light sys. & 150 & -45 & 195 \\
6 & Tanker & 5050 & 1960 & 3090 \\
7 & Full gas. load (40 cubic meters) & 29600 & 12840 & 16760 \\
8 & Net weight at zero load & 9415 & 2175 & 7240 \\
9 & Gross weight at full load & 39015 & 15015 & 24000 \\
\hline
\end{tabular}

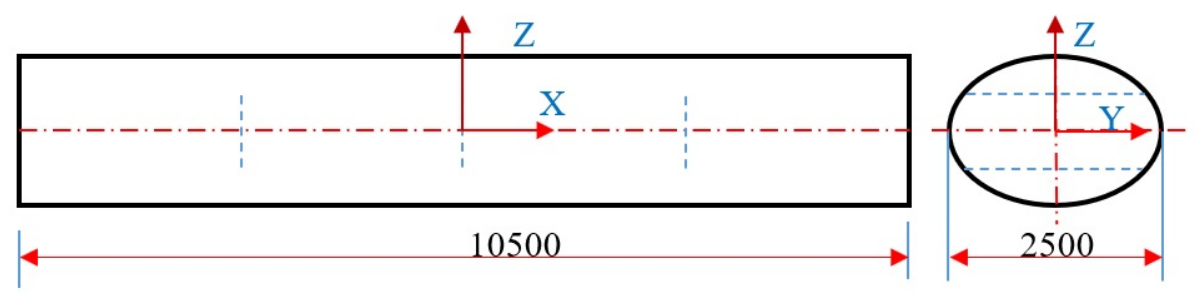

Figure 2: The tanker's geometry equipped with three lateral baffles 

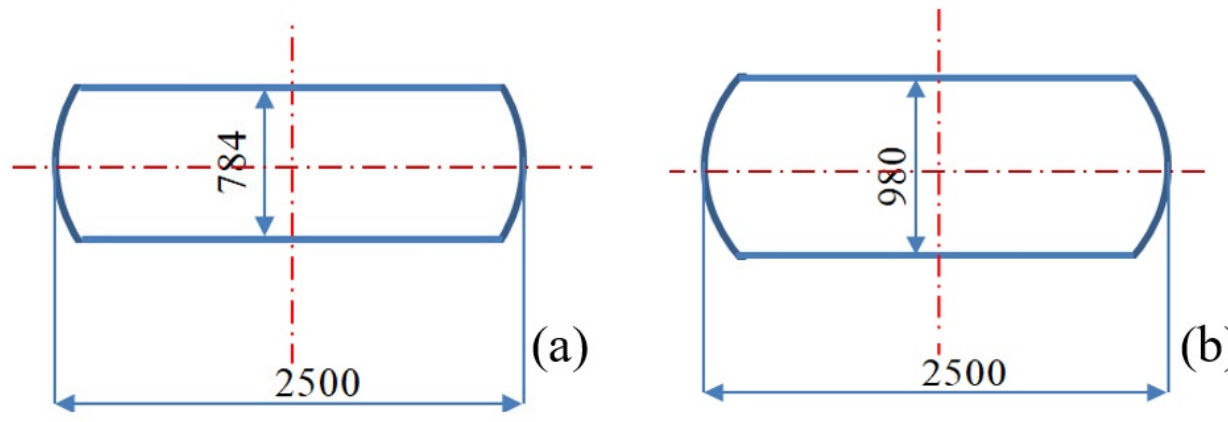

Figure 3: The shape of the baffle that have a height of $40 \%$ (a) and $50 \%$ (b)

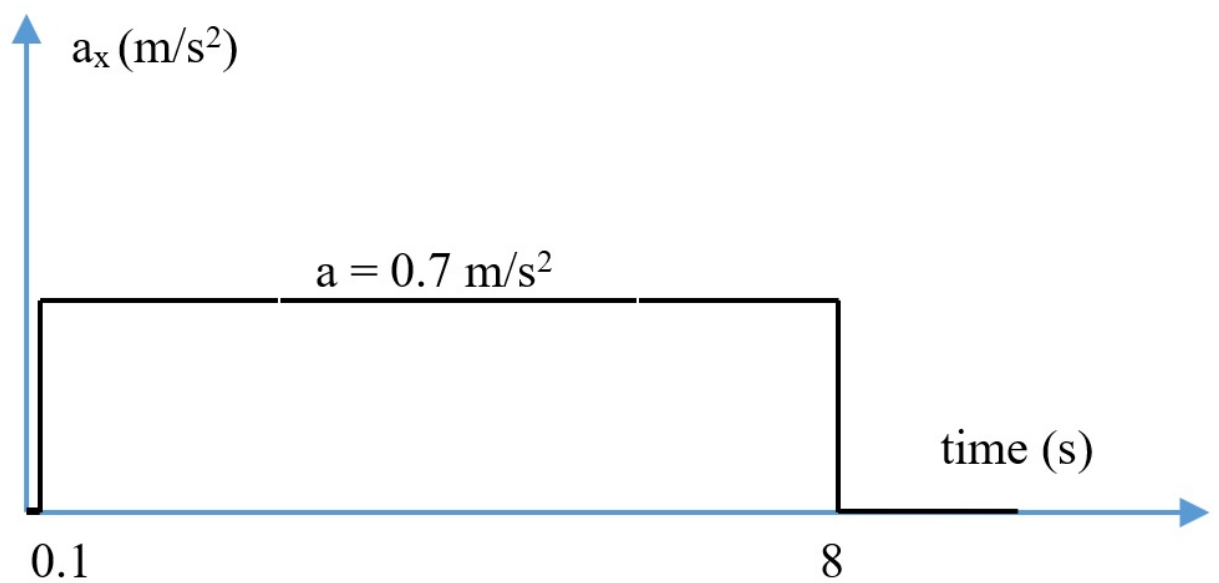

Figure 4: The acceleration excitation along the longitudinal axis.

Table 2: Detail of mesh quality for the case of 3 baffles

\begin{tabular}{llll}
\hline Quantity & $30 \%$ height & $40 \%$ height & $50 \%$ height \\
Sizing function & Uniform & Uniform & Uniform \\
Relevance center & Fine & Fine & Fine \\
Max face size & $0.16 \mathrm{~m}$ & $0.16 \mathrm{~m}$ & $0.16 \mathrm{~m}$ \\
Defeature size & $8 \mathrm{e}-04$ & $8 \mathrm{e}-04$ & $8 \mathrm{e}-04$ \\
Smoothing & Medium & Medium & Medium \\
Node & 10980 & 11499 & 14311 \\
Element & 5089 & 56025 & 55383 \\
\hline
\end{tabular}




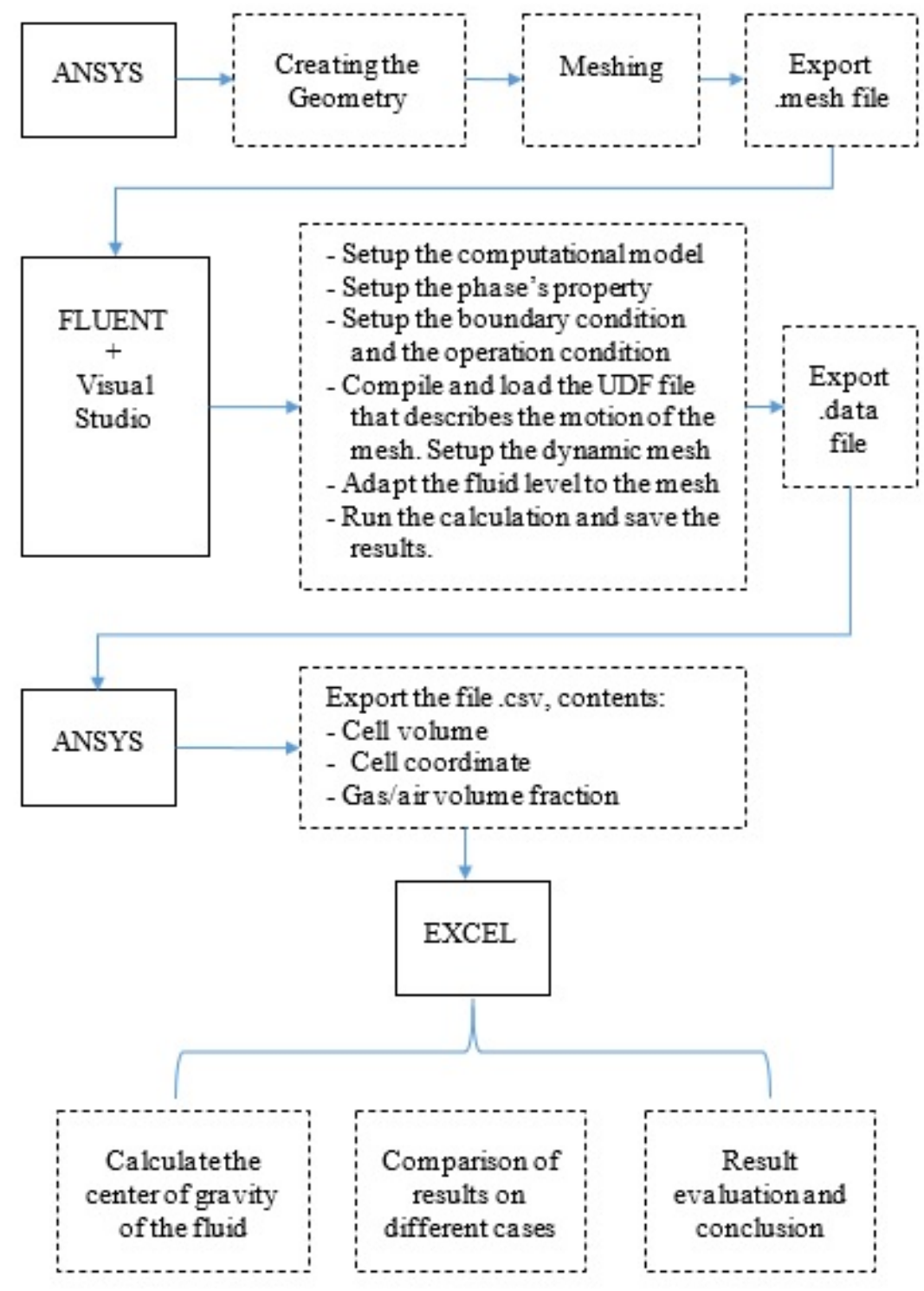

Figure 5: The process of simulation and result post processing

$-0<\operatorname{vof}(c)_{\text {gas }}<1$ : the cell is partially filled with gasoline (in the free surface between gasoline and air).

By assuming that the center of gravity of fluid in the free surface cell is at the centroid of the cell, the instantaneous center of gravity of the liquid in the tanker can be obtained from the volume integrals over the computational domain. Alternatively, for the discrete mesh, the estimation of the center of gravity is done by:

$X_{c g}=\frac{\Sigma x_{c} \cdot M_{c}}{\Sigma M_{c}}, Y_{c g}=\frac{\Sigma y_{c} \cdot M_{c}}{\Sigma M_{c}}, Z_{c g}=\frac{\Sigma z_{c} \cdot M_{c}}{\Sigma M_{c}}$
In which, $x_{c}, y_{c}, z_{c}$ are the coordinate of the centroid of the cell $c$ respect to the original coordinate of the tanker.

\section{RESULTS AND DISCUSSIONS}

\section{Static Stability}

The static stability of the trailer can be obtained by taking into account the load of gasoline to the change of the static center of gravity. As changing the liquid level, the load of fluid will be changed, while the weight of other components is remaining. Resulting 


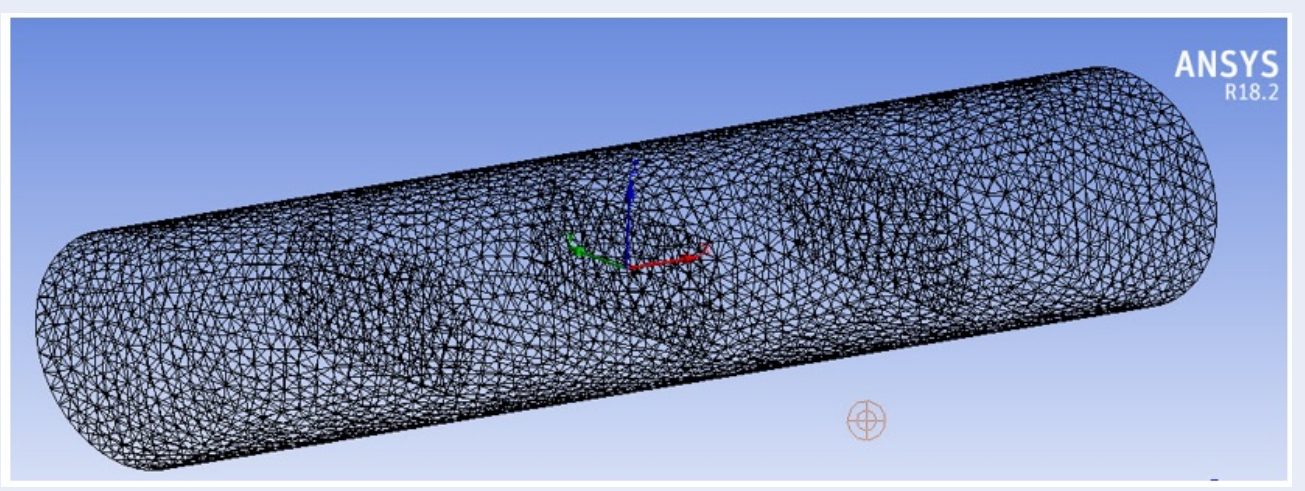

Figure 6: The wireframe mesh of tanker with 3 baffles, baffle height $=50 \%$

Table 3: Detail of model and parameter setting of the solver

\begin{tabular}{|c|c|}
\hline Model and parameter & Setting \\
\hline Solving type & $\begin{array}{l}\text { Pressure based, time tran- } \\
\text { sient }\end{array}$ \\
\hline Multiple phase model & Volume of Fluid \\
\hline $\begin{array}{l}\text { Number of Eulerian } \\
\text { phases }\end{array}$ & 2 \\
\hline $\begin{array}{l}\text { Volume fraction parame- } \\
\text { ter }\end{array}$ & Explicit \\
\hline Volume fraction cutoff & $1 e^{-06}$ \\
\hline Courant number & 0.25 \\
\hline Viscous model & Reliable k - epsilon \\
\hline Near wall treatment & Scalable wall function \\
\hline Pressure velocity coupling & SIMPLE \\
\hline Gradient model & Least squares cell based \\
\hline Pressure model & PRESTO \\
\hline Momentum model & Second order upwind \\
\hline Tracking surface method & Geo - Reconstruct \\
\hline Transient Formulation & First order implicit \\
\hline Primary phase & Air \\
\hline Secondary phase & Gasoline liquid \\
\hline Air density $\left(\mathrm{kg} / \mathrm{m}^{3}\right)$ & 1.225 \\
\hline Air viscosity $(\mathrm{kg} / \mathrm{m}-\mathrm{s})$ & $1.7894 \mathrm{e}-05$ \\
\hline $\begin{array}{l}\text { Gasoline density }\left(\mathrm{kg} / \mathrm{m}^{3}\right) \text { - } \\
\rho_{\text {gas }}\end{array}$ & 830 \\
\hline $\begin{array}{l}\text { Gasoline viscosity }(\mathrm{kg} / \mathrm{m} \text { - } \\
\mathrm{s})\end{array}$ & 0.00332 \\
\hline
\end{tabular}

in the shifting of the center of gravity, and the redistribution of load on the kingpin and the rear axles. The redistribution load on the kingpin and the rear axles at different mode of liquid fluid level are shown in Table 4 .

The distance from the center of gravity of the liquid fluid in the tanker to the kingpin can be calculated using the formulate: $L_{1}=L_{0} G_{2 t} / G_{t}=4.490 \mathrm{~m}$. In which, $L_{0}=7.930 \mathrm{~m}$ is the wheelbase of the trailer.

\section{Dynamic Stability}

The dynamic stability of the trailer is evaluated by calculating the shifting of load due to the sloshing of fluid under a time-varying acceleration excitation. At a certain level of fluid in the tanker, the free surface of the liquid will be changed as the sloshing is occurred. As a result, the location of the center of gravity of fluid is varied, leading to a redistribution of load on the kingpin and the rear axles.

The calculation of load on the kingpin during sloshing is done by: $G_{1 t}^{\prime}=G_{t} \cdot\left(L_{1}+\triangle x_{c g_{-} \tan k e r}\right) / L_{0}$. In which, $\triangle x_{c g_{-} \tan k e r}$ is the shifting of the center of gravity of the liquid fluid obtained from the post processing of simulation results. Therefore, the shifting of load on the kingpin due to sloshing can be obtained by: load shifting on the kingpin $=G_{1 t}^{\prime}-G_{1 t}$. Similarly, the load and the shifting of load on the rear axles can be obtained by applied the following formulates: $G_{2 t}^{\prime}=G_{t}-G_{1 t}^{\prime}$, and load shifting on the kingpin $=$ $G_{2 t}^{\prime}-G_{2 t}$.

\section{Effect of the Number of the Baffle on the Load Distribution}

To study the effect of the quantity of baffle to the dynamic stability of the semi-trailer, the lateral baffles are inserted to the tanker. The baffle's height equals $40 \%$ the height of the tanker, while the baffle quantity 


\section{Table 4: Load on the kingpin and the rear axles at different load mode of the tanker}

\begin{tabular}{llll}
\hline Load mode & $G_{t}:$ Gross weight $(\mathrm{kg})$ & $G_{1 t}:$ Load on kingpin $(\mathrm{kg})$ & $G_{2 t}:$ Load on rear axles $(\mathrm{kg})$ \\
$100 \%$ & 29600 & 12840 & 16760 \\
$90 \%$ & 11556 & 15084 \\
$70 \%$ & 26640 & 8988 & 11732 \\
$50 \%$ & 20720 & 6420 & 8380 \\
\hline
\end{tabular}

is set to be three, four, or five baffles. In these simulation cases, the gasoline is set up at $70 \%$ of the tanker volume. The simulation result in term of volume fraction of gasoline is depicted in Figure 7.

As seen in Figure 7a, b, c, the liquid fluid is moving toward the rear of the tanker at the time of observation. Therefore, it can be predicted that dynamic load will increase in the rear of the tanker, and decrease in the front of the tanker. Detail of the redistribution of load on the kingpin and the rear axles is shown in Table 5, the static gross weight of the trailer is $20720 \mathrm{~kg}$.

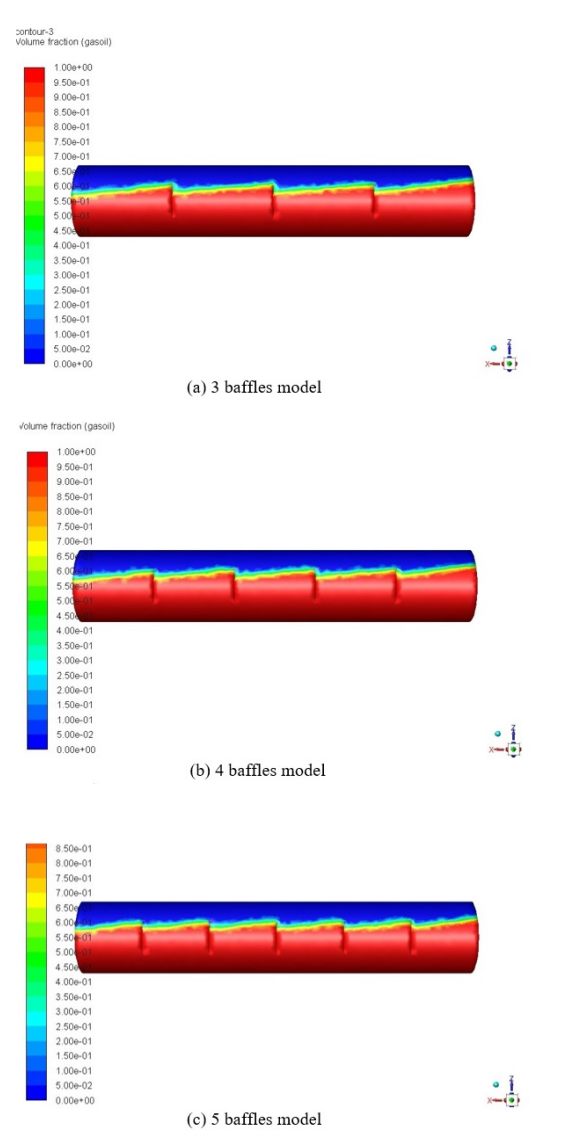

Figure 7: Volume fraction of gasoline on tanker model that has 3, 4, and 5 baffles
Figures 8 and 9 illustrate the amount of changing in the load distribution on the kingpin and the rear axles at different baffle configuration.

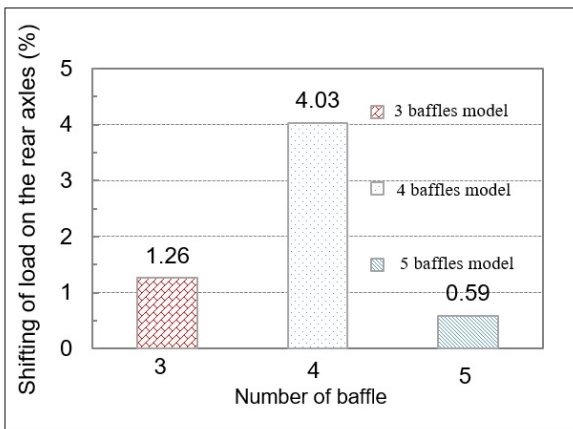

Figure 8: The shifting of load on the kingpin in tanker model that has 3, 4, and 5 baffles

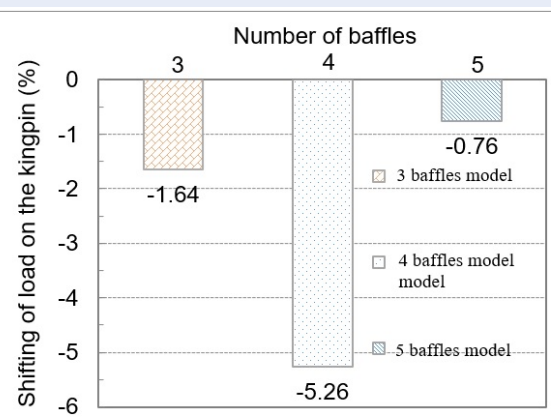

Figure 9: The shifting of load on the kingpin in tanker model that has 3,4 , and 5 baffles

As seen in Figure 8 and Figure 9, the baffles help to slow down the redistribution of load on the kingpin and the rear axles. The three and five baffle models give good results in preventing the shifting of the center of gravity of the trailer in comparison with the model of four baffles. At the time of observation, it can be recognized in all cases of the simulation that load is reduced on the kingpin and increase on the 
Table 5: Effect of the number of baffle on the load redistribution

\begin{tabular}{llllllc}
\hline \multirow{2}{*}{ Baffle model } & \multicolumn{2}{c}{ Static load $(\mathrm{kg})$} & \multicolumn{2}{c}{ Dynamic load $(\mathrm{kg})$} & \multicolumn{2}{c}{ Shifting of load (\%) } \\
& King-pin & Rear axles & King-pin & Rear axles & King-pin & Rear axles \\
3 baffles & 8988 & 11732 & 8841 & 11879 & -1.64 & 1.26 \\
4 baffles & 8988 & 11732 & 8516 & 12204 & -5.26 & 4.03 \\
5 baffles & 8988 & 11732 & 8919 & 11801 & -0.76 & 0.59 \\
\hline
\end{tabular}

rear axles.

In comparison to the three baffles model, the model with five baffles provides better resistance against the sloshing. The reduction of load on the kingpin of five baffles model $(0.76 \%)$ is lightly smaller than in the three baffles model (1.64\%). The increase of load on the rear axles of the five baffles model $(0.59 \%)$ is a little bit smaller as compared with the case of the three baffles model (1.26\%).

However, as evaluating the term of cost and simplicity, the three baffles model has more advantages than the five baffles model. Therefore, the tanker with three lateral baffles will be used for further study on the effect of baffle height on the longitudinal stability of the trailer.

Three baffle height of $30 \%, 40 \%$, and $50 \%$ are used to find out which model will give better results in reducing of shifting of the center of gravity of the trailer as under sloshing. The simulation results in terms of volume fraction of fluid for the liquid level of $50 \%$ are depicted in Figure 10a, b, c.

Detail of load distribution on the kingpin and the rear axles at the static condition and sloshing is shown in Table 6.

At the liquid fluid level of $50 \%$, the baffle model of $30 \%$ baffle height has less effect on reducing the movement of the fluid. As shown in Figure 10a, the fluid tends to move toward the right end of the tanker at the time of observation. Therefore, the dynamic load significantly increases on the rear axles of the tanker (24.99\%), and highly reduce on the kingpin (32.61\%). In the models that have a baffle height of $40 \%$ and $50 \%$, the baffles effectively limit the oscillation of fluid. As a result, the shifting of the center of gravity of the fluid is rather small as compared with the $30 \%$ baffle height model.

Among the three models of baffle height, the model of $40 \%$ baffle height gives the smallest movement of the center of gravity of the trailer, resulting in the smallest shifting of load on the kingpin and the rear axles ($3.33 \%$ and $2.55 \%$ ). This dominance of the $40 \%$ baffle height model will be validated on other liquid fluid levels of $70 \%$ and $90 \%$. The simulation result of these cases is detailed in Table 7 and Table 8.

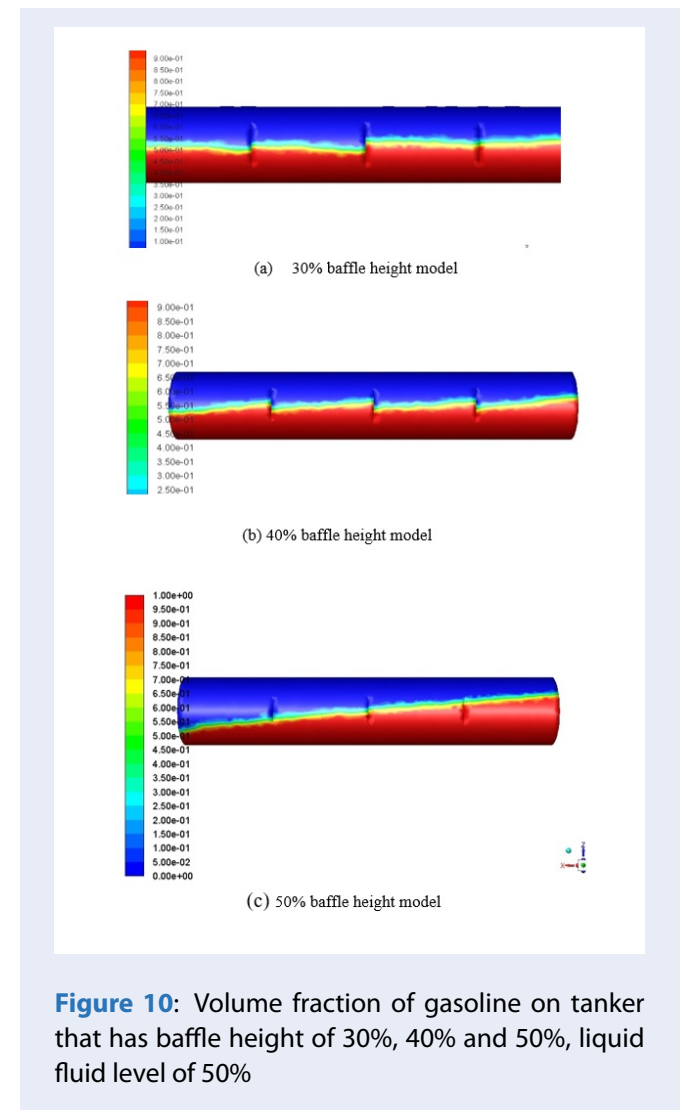

The simulation result of the $70 \%$ liquid level is similar to the case of the fluid level of $50 \%$. The $40 \%$ baffles' height model gives the best result in preventing the load shifting, while the largest load shifting occurs in the $30 \%$ baffles' height model. The volume fraction of gasoline for three models of baffle height is illustrated in Figure 11.

The result of load shifting for the case of $90 \%$ liquid level is shown in Table 8 . The volume of fluid on the computational domain is depicted in Figure 12. It can be seen that the fluid does not have much space for sloshing. With the baffle height of $30 \%$ and $40 \%$ the baffles nearly submerse in the liquid fluid and have less effect in reducing the fluid oscillation. Baffle height of $50 \%$ provides a better reduction of slosh- 


\begin{tabular}{lllllll}
\hline \multicolumn{7}{l}{ Table 6: Effect of baffle's height on the load redistribution - fluid level of $\mathbf{5 0 \%}$} \\
\hline $\begin{array}{l}\text { Baffle } \\
(\%)\end{array}$ & height & Static load $(\mathrm{kg})$ & Dynamic load $(\mathrm{kg})$ & Shifting of load (\%) \\
& King-pin & Rear axles & King-pin & Rear axles & King-pin & Rear axles \\
30 & 6420 & 8380 & 4326 & 10474 & -32.61 & 24.99 \\
40 & 6420 & 8380 & 6206 & 8594 & -3.33 & 2.55 \\
50 & 6420 & 8380 & 5853 & 8947 & -8.83 & 6.76 \\
\hline
\end{tabular}

Table 7: Effect of baffle's height on the load redistribution - fluid level of $70 \%$

\begin{tabular}{lllllll}
\hline \multirow{2}{*}{ Baffle height (\%) } & \multicolumn{2}{l}{ Static load $(\mathrm{kg})$} & \multicolumn{2}{l}{ Dynamic load $(\mathrm{kg})$} & \multicolumn{2}{l}{ Shifting of load (\%) } \\
& King-pin & Rear axles & King-pin & Rear axles & King-pin & Rear axles \\
30 & 8988 & 11732 & 7633 & 13087 & -15.07 & 11.55 \\
40 & 8988 & 11732 & 8841 & 11879 & -1.64 & 1.26 \\
50 & 8988 & 11732 & 8104 & 12616 & -9.83 & 7.53 \\
\hline
\end{tabular}

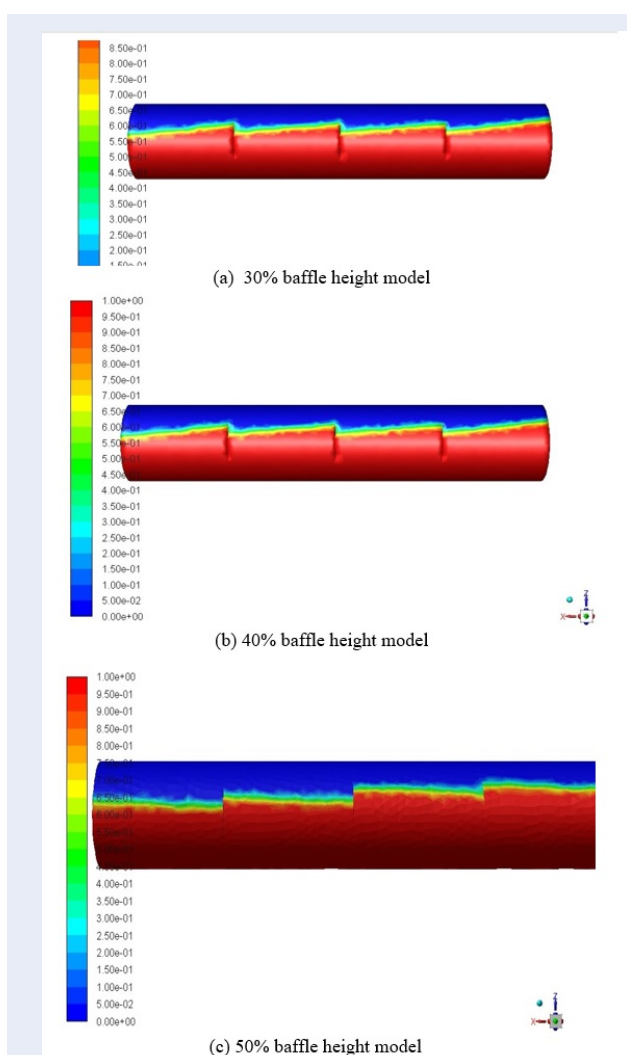

Figure 11: Volume fraction of gasoline on tanker that has baffle height of $30 \%, 40 \%$ and $50 \%$, liquid fluid level of $70 \%$ ing, resulting in the smallest load shifting in the kingpin and the rear axles among the three model of baffle height.

\section{CONCLUSIONS}

The study of the effect of adding lateral baffles on the longitudinal stability of a tanker semi-trailer has been conducted by using a computational fluid dynamics approach. Lateral baffles characteristic in terms of a number of the baffle, and height of baffle have been examined to find out the appropriate baffle configuration.

It could be concluded that the simulation approach using multiphase Volume of Fluid Model in Ansys Fluent can be used to capture the air-liquid fluid interface. Analyses of the simulation results show that lateral baffles could be damping the oscillation of fluid under sloshing.

The $40 \%$ height three baffles model is the proper tanker model to resist the longitudinal sloshing in the partially filled tanker of the studied trailer.

Validation on different liquids levels shows that the effectiveness of the baffle against the sloshing is high at a low liquid level. This effect reduces as the tanker is full or nearly full of liquid.

\section{LISTS OF ABBREVIATIONS}

CFD: Computational Fluid Dynamics

UDF: User Defined Function

VOF: Volume Of Fluid

\section{CONFLICTS OF INTEREST}

The authors declare that they have no conflicts of interest. 


\section{Table 8: Effect of baffle's height on the load redistribution - fluid level of $\mathbf{9 0 \%}$}

\begin{tabular}{lllllll}
\hline \multirow{2}{*}{ Baff height (\%) } & \multicolumn{2}{l}{ Static load $(\mathrm{kg})$} & \multicolumn{2}{l}{ Dynamic load $(\mathrm{kg})$} & \multicolumn{2}{l}{ Shifting of load (\%) } \\
& King-pin & Rear axles & King-pin & Rear axles & King-pin & Rear axles \\
30 & 11556 & 15084 & 10445 & 16195 & -9.61 & 7.37 \\
40 & 11556 & 15084 & 10574 & 16066 & -8.5 & 6.51 \\
50 & 11556 & 15084 & 10790 & 15850 & -6.63 & 5.08 \\
\hline
\end{tabular}

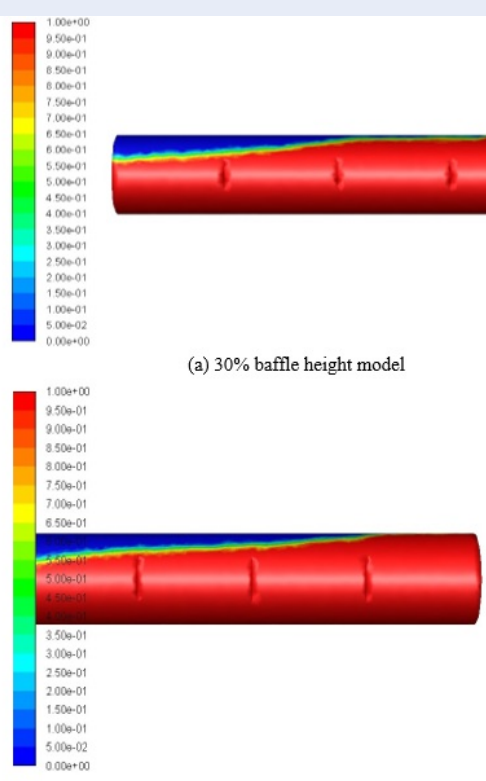

(b) $40 \%$ baffle height model

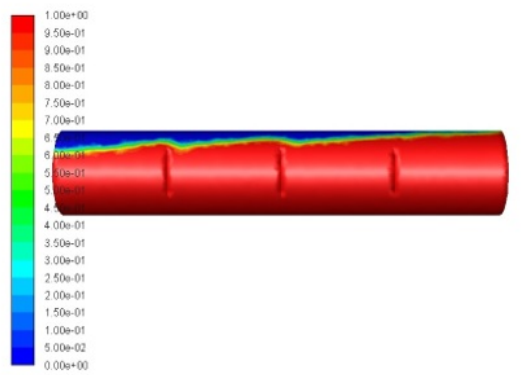

(c) $50 \%$ baffle height model

Figure 12: Volume fraction of gasoline on tanker that has baffle height of $30 \%, 40 \%$ and $50 \%$, liquid fluid level of $90 \%$

\section{AUTHOR CONTRIBUTION}

The contribution of each author in this paper is listed as below:

Hong Duc Thong contributes in the supervision, project administration, and writing \& editing. Tran Minh Tai contributes in conducting the research and investigation process, and analyzing the simulation data.

Huynh Phuoc Thien contributes in the supervision, developing of methodology, and writing \& editing.

\section{REFERENCES}

1. Wang LS, Wang Z, Li YC. Two-dimensional nonlinear parametric sloshing in the irregular tanks: numerical analysis and experimental investigation. JVE International Itd. Journal of Vibroengineering. 2016;19:2153 -2163. Available from: https: //doi.org/10.21595/jve.2016.17217.

2. Ha M, Kim D, Choi HI, Cheong C, Kwon SH. Numerical and experimental investigations into liquid sloshing in a rectangular tank. Proc. The 2012 World Congress on Advances in Civil, Environmental, and Materials Research, Seoul, Korea. 2012;p. 3546 $-3553$.

3. Kandasamy T, Rakheja S, Ahmed AKW. An Analysis of Baffles Designs for Limiting Fluid Slosh in Partly Filled Tank Trucks. The Open Transportation Journal. 2010;4:23 -32. Available from: https://doi.org/10.2174/1874447801004010023.

4. Singala V, Bajajb J, Awalgaonkara N, Tibdewalc S. CFD Analysis of a Kerosene Fuel Tank to Reduce Liquid Sloshing. Procedia Engineering. 2014;69:1365 -1371. Available from: https: //doi.org/10.1016/j.proeng.2014.03.130.

5. G43-BX40-02 Tanker Semi Trailer specification, [Online]. Accessed on August 1st, 2019;Available from: https://tanthanhcontainer.com/wp-content/uploads/2018/ 06/G43-BX40-02-E.pdf.

6. Tai TM. Nghiên Cứu Tối Uu Vách Ngăn Xi-Téc Để Nâng Cao Tính Năng Đông Lực Học Của Sơmi Rơ-Moóc Chở Xăng", M.S. thesis, Depart. of Automotive and Engine, Hochiminh City University of Technology, HCM city, VN. 2019;.

7. Simulation of Wave Generation in a Tank, Fluent Tutorial, [Online]. Accessed on August 1st, 2019.;Available from: http:// willem.engen.nl/uni/fluent/documents/external/wave.pdf. 


\title{
Nghiên cứu tác dụng của vách ngăn đối với sự ổn định dọc của sơmi rơ-moóc chở xăng sử dụng phương pháp mô phỏng số
}

\author{
Hồng Đức Thông ${ }^{1,2}$, Trần Minh Tài ${ }^{1,3}$, Huỳnh Phước Thiện ${ }^{3, *}$
}

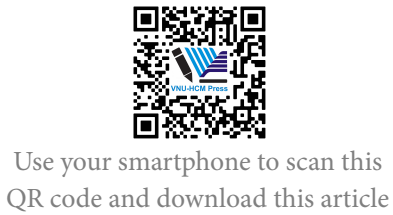

${ }^{1} B \hat{o}$ Môn Kỹ Thuật Ô tô - Máy Động Lực, Khoa Kỹ thuật Giao thông, Trương Đại học Bách Khoa TPHCM

${ }^{2} Đ a ̣ i$ học Quốc gia Thành phố Hồ Chí Minh

${ }^{3}$ Bộ Môn Ô tô, Khoa Cơ khí Động lực, Trường Cao đảng Kỹ thuật Cao Thẳng

Liên hệ

Huỳnh Phước Thiện, Bộ Môn Ô tô, Khoa Cơ khí Động lực, Trường Cao đẳng Kỹ thuật Cao Thắng

Email: huynhphuocthien@caothang.edu.vn

Lịch sủ

- Ngày nhận: 09-8-2019

- Ngày chấp nhận: 27-12-2020

- Ngày đăng: 22-01-2021

DOI : 10.32508/stdjet.v3iSI2.538

\section{Check for updates}

\section{Bản quyền}

๑ ĐHQG Tp.HCM. Đây là bài báo công bố mở được phát hành theo các điều khoản của the Creative Commons Attribution 4.0 International license.

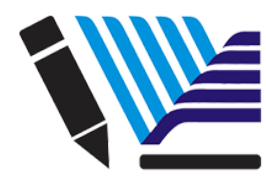

VNU-HCM Press

\section{TÓM TẮT}

Sự sóng sánh của chất lỏng trong bồn chứa không đầy tải có ảnh hưởng rất lớn đến ổn định dọc và sự vận hành an toàn của sơmi rơmóc bôn nhiên liệu. Khi xe chuyển hướng, tăng tốc hoặc phanh, chất lỏng trong bồn có xu hướng dao động. Kết quả là các lực và mô men thủy động sẽ xuất hiện làm giảm giới hạn ổn định và khả năng điêu khiển của xe. Để hạn chế tác động của dao động sóng sánh, các vách ngăn thường được thêm vào cấu trúc của bồn. Trong bài báo này, nghiên cứu về tác dụng của vách ngăn đối với sự ổn định dọc của sơmi rơ-moóc chở xăng sử dụng phương pháp số sẽ được trình bày. Một mô hình tính toán số ba chiều với các cấu trúc khác nhau của vách ngăn được xây dựng phục vụ cho việc mô phỏng. Hàm được định nghĩa bởi người dùng (UDF) được sủ dụng để điều khiển gia tốc của bồn chứa trong quá trình mô phỏng. Mô phỏng được tiến hành cho trường hợp xe được gia tốc đều theo phương dọc trục với các mức tải khác nhau trong bồn chở xăng. Tỷ lệ thể tích chất lỏng (VOF) thu được từ quá trình mô phỏng được sử dụng để tính toán vi trí trong tâm của bồn chứa khi xảy ra sự song sánh của chất lỏng. Việc phân tích kết quả mô phỏng cho thấy các vách ngăn có khả năng chống lại các dao động sóng sánh trong bồn, kết quả là làm cải thiện ổn định dọc của phương tiện. Các kết quả tính toán cũng cho thấy ổn định dọc của xe bôn phụ thuộc vào số lượng và kích thước của vách ngăn. Mô hình bồn với ba vách ngăn có chiều cao vách bằng 40\% chiêu cao bôn cho kết quả tốt nhất trong việc làm giảm thiểu sư sóng sánh của chất lỏng theo phương doc truc trên xe bôn khảo sát. Bằng cách thêm vào các vách ngăn, sự thay đổi tải trọng trên chốt kéo và trên trục sau có thể nhỏ hơn $5 \%$ và $2 \%$ khi mức xăng trong bồn lần lượt ở mức 50\% và 70\% chiều cao bồn.

Từ khoá: Vách ngăn, ổn định dọc của chất lỏng trong bôn, mô phỏng sự sóng sánh của chất lỏng trong bồn chứa, xe bồn
Trích dẫn bài báo này: Thông $\mathrm{H} D$, Tài $\mathrm{T} M$, Thiện $\mathrm{H}$ P. Nghiên cứu tác dụng của vách ngăn đối với sự ổn định dọc của sơmi rơ-moóc chở xăng sử dụng phương pháp mô phỏng số. Sci. Tech. Dev. J. - Eng. Tech.; 3(SI2):SI13-SI23. 